\title{
Time Series Modeling of Inflation and its Volatility in Croatia
}

\section{Modeliranje inflacije i njezine promjenjivosti u Republici Hrvatskoj primjenom analize vremenskih serija}

\begin{abstract}
Croatian National Bank is not targeting inflation but exchange rate as the nominal anchor or intermediary goal of monetary policy and inflation in Croatia is a dominantly foreign driven phenomenon. Using monthly data on CPI in Croatia from January 1997 up to November 2015, ARIMA $(0,1,1) \times(0,1,1)_{12}$ model is fitted as the one describing CPI behavior pattern and therefore reliable for CPI forecasting. Furthermore, to establish its volatility pattern several ARCH family models are tested and ARCH (1) model is found to be the best fitted one in explaining CPI volatility development in Croatia.
\end{abstract}

Keywords: CPI,ARIMA, ARCH, Croatia

JEL classification: C22, C58, E31, E37, F39

\section{Sažetak}

Hrvatska narodna banka ne temelji monetarnu politiku na ciljanju inflacije te devizni tečaj služi kao intermedijarni cilj i temelj vođenja monetarne politike u Republici Hrvatskoj. Inflacija u Republici Hrvatskoj dominantno je određena stopama inflacije u inozemstvu. Na uzorku mjesečnih podataka o indeksu potrošačkih cijena u Republici Hrvatskoj od siječnja 1997. do studenog 2015. prilagođen je ARIMA $(0,1,1) \times(0,1,1)_{11}$ model koji opisuje dinamiku kretanja indeksa potrošačkih cijena u Republici Hrvatskoj. Procijenjeni model se može koristiti za pouzdano prognoziranje kretanja potrošačkih cijena u Republici Hrvatskoj. Nadalje, kako bi se istražile karakteristike promjenjivosti indeksa potrošačkih cijena testirano je nekoliko ARCH modela. Provedeni testovi su pokazali da ARCH (1) model najbolje objašnjava promjenjivost indeksa potrošačkih cijena u Republici Hrvatskoj

Ključne riječi: CPI,ARIMA, ARCH, Hrvatska

\section{JEL klasifikacija: C22, C58, E31, E37, F39}

\section{Introduction}

The debate on monetary policy and exchange rate, and its adequacy in the case of Croatia, started with the Stabilization Program implementation in the fall of 1993, and is still in progress. Besides the high euroization in the financial system, Croatian economy is characterized as a highly open and having relatively high level of external debt as well.

Globan et al. (2016) empirically analyzed the do- mestic and external inflation determinants for eight non-Eurozone new EU member states including Croatia, using a structural vector autoregression model and found that foreign shocks are a major factor in explaining inflation dynamics in the medium run. This might be the case due to relatively high imports in Croatia and so inflation in Croatia is determined by costs and not by money supply. However, stable inflation is important for sound macroeconomic and financial conditions as well as
Assoc. prof. Igor Živko, PhD

Faculty of Economics and Business, University of Mostar

E-mail:igor.zivko@sve-mo.ba

Asst. prof. Mile Bošnjak, PhD

Faculty of Economics and Business, University of Zagreb

E-mail: mbosnjak1@efzg.hr

\section{Izv. prof.dr.sc. Igor Živko}

Ekonomski fakultet Sveučilišta u Mostaru E-mail:igor.zivko@sve-mo.ba

\section{Doc. dr.sc.Mile Bošnjak}

Ekonomski fakultet Sveučilišta u Zagrebu E-mail:mbosnjak1@efzg.hr 
Živko, I., Bošnjak, M.

Time Series Modeling of Inflation and its Volatility in Croatia for fostering economic development (Goodfriend, 2007). Since the financial crisis in 2007 through various monetary policy measures central banks balance sheet has expanded significantly indicating a high increase in money supply (Joyce et al. 2012). Furthermore, economic theory and historical experience suggest that a significant and persistent expansion in the money supply will be associated with a significant increase in the longer-run inflation rate. If later is true, Croatia might experience inflation rate increase. At the same time, Croatian National Bank copes with retaining EUR/HRK exchange rate stability. According to Chmelarova and Schnabl (2006), Croatian foreign exchange intervention manage both day-to-day exchange rate volatility as well as exchange rate levels. Furthermore, the authors concluded that the pattern of foreign exchange intervention for Croatia confirms a fear of depreciation (with respect to balance sheet effects of the banking sector) more than the fear of appreciation (with respect to export competitiveness). The Croatian National Bank, in order to meet its primary objective and maintain price stability, keeps the stability of the EUR/HRK exchange rate (Palić, et al., 2014; Mance et al., 2015). So conclusively, due to high euroization in commercial banks' balance sheet, the Croatian National Bank does not target inflation in Croatia. But, as a consequence of monetary expansion in the European Monetary Union (EMU), at one point Croatia might experience adverse effects out of imported inflation from the EMU. To describe inflation and its volatility patterns it's necessary to apply adequate econometric models. So the main aim of this paper is to apply the model of inflation and its volatility as well.

The rest of the paper is organized as follows: Section 2 briefly summarizes existing relevant literature. Section 3 presents research data and methodology, while Section 4 presents empirical results and discussion. The final section provides an overview of the main findings of the research.

\section{Brief related literature overview}

The literature on inflation forecasting points to different modeling techniques in forecasting inflation. Some authors found VAR models accurate in forecasting inflation (Fritzeret al., 2002; Hubrich, 2005). Espasa et al. (2002), point out that ARIMA models outperform the VECM and dynamic factor models. However, numerous literature supports the forecasting strength of ARIMA as a modeling technique in forecasting inflation (Libert, 1983; Hill and Fildes, 1984; Poulos et al., 1987; Texter and Ord, 1989; Bokhari and Feridun, 2006; Etuk et al., 2012; Kelikume and Salami, 2014).

Inflation in Croatia has been the topic of much previous research and to the best knowledge of the authors, the last one was done by Vizek and Broz (2009). The model of inflation derived by Vizek and Broz (2009) suggests that inflation inertia and Croatian trading partners' inflation are most important for explaining the short-run behavior of inflation. Apart from these two variables, the authors found the contribution of markup, excess money, output gap, nominal exchange rate, and broad money to inflation changes in the short-run. Payne (2002) explores the inflationary dynamics in Croatia using vector autoregression (VAR) over the period from January 1992 to December 1999. The model results suggest that wage increases and currency depreciation are positively correlated with inflation rates. Botrić and Cota (2006) model Croatian inflation dynamics using the VAR. They found that the terms of trade and balance of payment shocks have the strongest impact on prices. Pufnik and Kunovac (2006) used ARIMA method to estimate inflation and research strategy that is the most similar to the one in the present paper. At the very beginning of the paper, Kunovac (2006) considered the main problems associated with the characteristics of the Consumer Price Index (CPI) series in Croatia at that time (length of the series, changes in the methodology, structural breaks). Nowadays the aforementioned problems are resolved and we want to establish a reliable model of CPI development and its volatility.

\section{Data and research methodology}

Consumer Price Index measures the change in the general price level of goods and services that households acquire for the purpose of consumption over certain time period, with reference to the price level in 2015, as the base year, which has an index of 100 . For the research purpose, we use the monthly data,from January 1997 up to November 2015, on CPI as shown in Figure 1. The data is provided by 
Figure 1 Monthly CPI in Croatia from January 1997 to November 2015

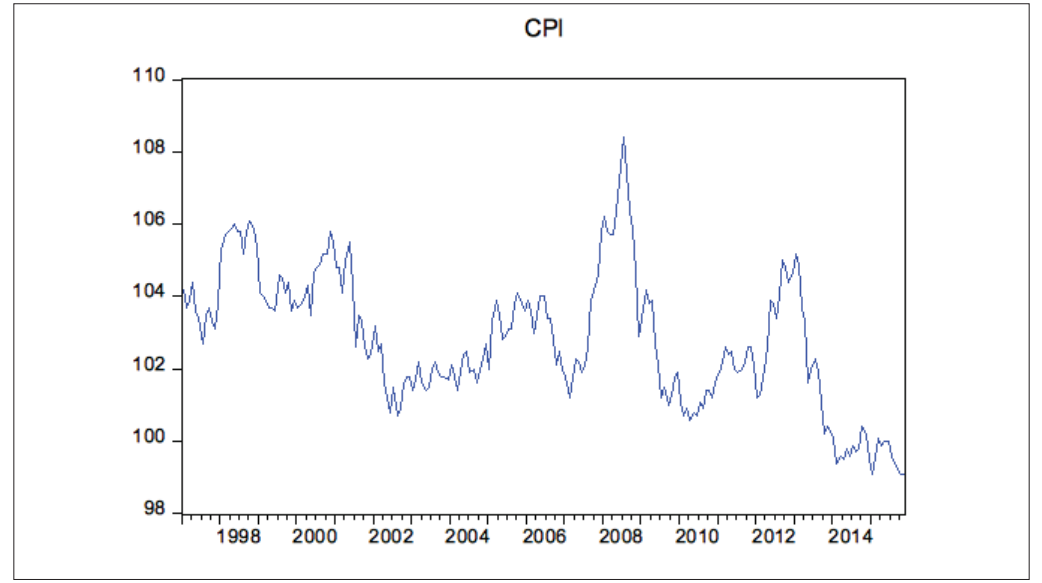

Source: the authors.

the Croatian Bureau of Statistics.

The data in Figure 1 indicates an overall decrease in CPI with some exceptions and potential non-stationary time series with some seasonality. The descriptive statistics for the observed data is provided in Table 1.

Following the descriptive statistics from Table 1 , Skewness, Kurtosis and eventually Jarque-Bera test results support normality assumptions and so we do not need to consider alternative distributions to be used as a basis for modeling CPI in Croatia (like it is often the case when modeling financial time series, see for example Erjavec and Cota, 2007).

The first question in any time series analysis is whether the time series is stationary or not. So we start the research with unit root tests. The unit root tests we perform are based on the assumption that a time series data $\left\{Y_{t}\right\}$ follows a random walk.

Where $\rho$ is the characteristic root of an AR polynomial and $\varepsilon_{t}$ is purely a random process with mean zero and variance $\sigma^{2}$.

Autoregressive Integrated Moving Average (ARIMA) is a well-known forecasting technique that projects the future values of a time series, and the future value of a series or forecasts are entirely based on

$$
\begin{array}{|l|l|}
Y_{t}=\rho Y_{t-1}+\varepsilon_{t} & 1 \\
\hline
\end{array}
$$

its own behavior in the past. ARIMA models are simple, robust and parsimonious while providing
Živko, I., Bošnjak, M.

Time Series Modeling of Inflation and its Volatility in Croatia

Table 1 Descriptive statistics for Consumer Price Index in Croatia

\begin{tabular}{|c|c|}
\hline Variable & CPI \\
\hline Mean & 102,8260 \\
\hline Median & 102,6000 \\
\hline Maximum & 108,4000 \\
\hline Minimum & 99,1000 \\
\hline Standard deviation & 1,8605 \\
\hline Skewness & 0,1602 \\
\hline Kurtosis & 2,6277 \\
\hline Jarque-Bera & 2,2820 \\
\hline Probabilitiy & 0,3195 \\
\hline Number of observations & 227 \\
\hline
\end{tabular}

Source: the authors. 
Živko, I., Bošnjak, M.

Time Series Modeling of Inflation and its Volatility in Croatia

good results at the same time.

A time series $Y$, fits ARIMA model if the $d^{\text {th }}$ differences $\left(\nabla^{d} Y_{\text {t) }}\right)$ follow a stationary ARMA model. ARIMA process is described by three main components (see for example Cryer and Chan, 2008):

- $p$ - the order of the autoregressive component

- $d$ - the order of integration or the number of differencing needed to arrive at a stationary $\operatorname{ARMA}(p, q)$ process

- $q$ - the order of the moving average component The general ARIMA $(p, d, q)$ form is represented by the equation (2):

$\Phi(B)(1-B)^{d} Y_{t}=\theta(B) \varepsilon_{t}$ 2

The corresponding AR and MA characteristic polynomial are:

$$
\Phi(B)=\left(1-\Phi_{1} B-\Phi_{2} B^{2}-\cdots-\Phi_{p} B^{p}\right)
$$

$$
\theta(B)=\left(1-\theta_{1} B-\theta_{2} B^{2}-\cdots-\theta_{q} B^{q}\right)
$$

Where

$\Phi$ - is the parameter estimate of the Autoregressive component,

$\theta$ - is the parameter estimate of the Moving Average component,

$B$ - is the backward shift operator and

$\boldsymbol{\nabla}$ - is the difference operator that can be expressed by equation (5).

$\varepsilon_{t}$ - is a random process with mean zero and $\operatorname{var}\left(\varepsilon_{t}\right)=\sigma_{\varepsilon}^{2}$

$$
\nabla=(1-B)
$$

In the case where $p=0$, the model described by equations (2) to (4) becomes a moving average model of order $q$ or MA $(q)$ and in case of $q=0$ it becomes an autoregressive process of order $p$ or $\mathrm{AR}(p)$ Besides stationarity, the other requirement is invertibility or uniqueness of the covariance structure of the time series (Priestley, 1981), allowing for a meaningful association of current moves with the history of the series (Box and Jenkins, 1976). The autocorrelation function of an MA $(q)$ process cuts off after lag $q$ while for an AR $(p)$ process the autocorrelation function is a combination of sinusoidals dying off slowly. In the same way, partial autocorrelation function of an MA $(q)$ process dies off slowly while for an AR $(p)$ process cuts off after lag $p$. Stationarity and invertibility conditions for the model described by equation (2) require that equations (6) and (7) should have roots outside the unit circle respectively.

\begin{tabular}{|c|c|}
\begin{tabular}{|l|l|}
\hline$\left(1-\Phi_{1} B-\Phi_{2} B^{2}-\cdots-\Phi_{p} B^{p}\right)=0$ & 6 \\
\hline$\left(1-\theta_{1} B-\theta_{2} B^{2}-\cdots-\theta_{q} B^{q}\right)=0$ & 7 \\
\hline
\end{tabular}
\end{tabular}

A time series often exhibits seasonal pattern behavior or pattern behavior contains some component that appears periodically. The time series $\left[Y_{t}\right]$ follow a multiplicative seasonal ARIMA $(p, d, q) \times(P, D, Q)_{s}$ if it satisfies equation (8).

$\Phi(B) \varphi\left(B^{s}\right)(1-B)^{d}\left(1-B^{s}\right)^{D} Y_{t}=\theta(B) \cdot \omega\left(B^{s}\right) \varepsilon_{t} \quad 8$

Where $B$ is the standard backward shift operator like above defined, $\varphi$ and $\omega$ the seasonal moving average (MA) and autoregressive (AR) polynomials of order $\mathrm{P}$ and $\mathrm{Q}$ in variable $\boldsymbol{B}^{S}$.

\begin{tabular}{|c|c|}
\hline$\varphi\left(B^{s}\right)=1-\varphi_{1} B^{s}-\varphi_{2} B^{2 s}-\cdots-\varphi_{p} B^{p s}$ & 9 \\
\hline$\omega\left(B^{s}\right)=1-\omega_{1} B^{s}-\omega_{2} B^{2 s}-\cdots-\omega_{q} B^{q s}$ & 10 \\
\hline
\end{tabular}

Where $\varphi$ and $\omega$ are constants such that the zeros of the equations (9) and (10) are all outside the unit circle for stationarity and invertibility respectively. Equation (9) represents the autoregressive operator whereas equation (10) represents the moving average operator. The existence of seasonality is often evident from the time plot. Extensive details on ARIMA modeling can be found in Box and Jenkins (1976) as well as Madsen (2008).

Following the described procedure, we applied a seasonal ARIMA model to CPI in Croatia and obtained a model to forecast inflation in Croatia. To obtain the information on CPI volatility we employed several autoregressive conditional heteroscedasticity (ARCH) models. Namely, Engle's (1982) ARCH model specified by the equation (11), Bollerslev (1986) Generalized ARCH model (GARCH) given by the equation (12), the TARCH specification by 
Glosten et al. (1993) as well as Zakoian (1994) specified by the equation (13), the Exponential GARCH (EGARCH) introduced by Nelson (1991) and given by the equation (14) and the Power-ARCH (PARCH) specification introduced by Ding et al. (1993) described in the equation (15).

\begin{tabular}{|c|c|}
\hline$\sigma_{t}^{2}=\omega+\alpha \cdot \varepsilon_{t-1}^{2}$ & 11 \\
\hline$\sigma_{t}^{2}=\omega+\alpha \cdot \varepsilon_{t-1}^{2}+\beta \cdot \sigma_{t-1}^{2}$, & 12 \\
\hline$\sigma_{t}^{2}=\omega+\alpha \cdot \varepsilon_{t-1}^{2}+\gamma \cdot \varepsilon_{t-1}^{2} \cdot d_{t-1}+\beta \cdot \sigma_{t-1}^{2}$ & 13 \\
\hline $\log \left(\sigma_{t}^{2}\right)=\omega+\sum_{j=1}^{q} \beta_{j} \cdot \log \left(\sigma_{t-j}^{2}\right)$ & 14 \\
$+\sum_{i=1}^{p} \alpha_{i} \cdot \mid \frac{\varepsilon_{t-i}}{\sigma_{t-i}}+\sum_{k=1}^{r} \gamma_{k} \cdot \frac{\varepsilon_{t-k}}{\sigma_{t-k}}$ & \\
\hline$\sigma_{t}^{\delta}=\omega+\sum_{j=1}^{q} \beta_{j} \cdot \sigma_{t-j}^{\delta}+\sum_{i=1}^{p} \alpha \cdot\left(\left|\varepsilon_{t-1}\right|-\gamma_{i} \cdot \varepsilon_{t-i}\right)^{\delta}$ & 15 \\
\hline
\end{tabular}

Eventually, each model that is fitted to the data should be tested for goodness-of-fit. If the model is correct, the residuals would be uncorrelated and they would follow a normal distribution with mean zero and constant variance.

\section{Research results and discussion}

Before stating the estimation procedure we tested stationarity properties of the observed series. Unit root test results presented in Table 2 indicate that the monthly CPI in Croatia is not stationary at levels but integrated of order one.

In our example, estimating the model using the data at first differences does not remove autocor- relations in residuals of the estimated model so the ACF and PACF are insightful.

Our aim now is to find an appropriate ARIMA model based on the ACF and PACF shown in Figure 2. The significant spike at lag 1 in the ACF suggests a non-seasonal MA (1) component, and the significant spike at lag 12 in the ACF suggests a seasonal MA (1) component.ACF and PACF shown in Figure 2 show no other significant spikes. Consequently, we are going to fit the ARIMA $(0,1,1) \times(0,1,1)_{12}$ model, indicating a first and seasonal difference, and non-seasonal and seasonal MA (1) components. The $\operatorname{ARIMA}(0,1,1) \times(0,1,1)_{12}$ model is further estimated using the given equation (16).

\begin{tabular}{|c|c|}
\hline$\widehat{Y}_{t}=Y_{t-12}+Y_{t-1}-Y_{t-13}-$ & 16 \\
$\theta \cdot \epsilon_{t-1}-\vartheta \cdot \epsilon_{t-12}+\theta \cdot \vartheta \cdot \epsilon_{t-13}+\varepsilon_{t}$ & \\
\hline
\end{tabular}

The estimates for the proposed model described in equation (16) are obtained using maximum likelihood method as an estimator and results are provided in Table 3.

The estimated model is stable since all roots have modulus less than one and lie inside the unit circle, and correlogram indicates no autocorrelation in residuals up to leg thirty-six. Following Jarque-Bera tests, residuals in the estimated model are normally distributed ( $p$-value amounts 0.7337). The ARCH test indicates homoskedastic variance of residuals at a significance level of $5 \%$ ( $p$-value amounts 0.0251) and so the estimated model can be accepted. The estimates we obtained are consistent with Etuk et al. (2012) who documented the same pattern of inflation behavior in Nigeria. But nonetheless, there is some space to improve the efficiency of the estimated model and to obtain the estimates

Table 2 Unit root test results

\begin{tabular}{|c|c|c|c|c|}
\hline variable and test & \multicolumn{2}{|c|}{ Levels } & \multicolumn{2}{|c|}{ First difference } \\
\hline & constant & constant and trend & constant & constant and trend \\
\hline ADF test & \multicolumn{4}{|c|}{$\begin{array}{c}\text { t-stat } \\
\text { (p-value) }\end{array}$} \\
\hline \multirow[b]{2}{*}{ CPI } & -1.914606 & -2.543838 & -6.092619 & -6.071872 \\
\hline & $(0.3252)$ & $(0.3068)$ & $(0.0000)$ & $(0.0000)$ \\
\hline PP test & \multicolumn{4}{|c|}{$\begin{array}{c}\text { t-stat } \\
\text { (p-value) }\end{array}$} \\
\hline \multirow[b]{2}{*}{$\mathrm{CPI}$} & -2.071437 & -2.788073 & -13.16809 & -13.15676 \\
\hline & $(0.2566)$ & $(0.2033)$ & $(0.0000)$ & $(0.0000)$ \\
\hline KPSS test & \multicolumn{4}{|c|}{ LM-stat } \\
\hline CPI & 0.670489 & 0.099285 & 0.051042 & 0.034255 \\
\hline
\end{tabular}

Source: the authors. 
Živko, I., Bošnjak, M.

Time Series Modeling of Inflation and its Volatility in Croatia

Table 3 ARIMA $(0,1,1) \times(0,1,1)_{12}$ model summary for CPI in Croatia

\begin{tabular}{|c|c|c|c|c|}
\hline Model term & Coefficient & Standard error & t-statistic & P-value \\
\hline $\boldsymbol{\theta}$ & 0,139104 & 0,058475 & 2,378862 & 0,0182 \\
\hline $\boldsymbol{\theta}$ & $-0,750677$ & 0,065112 & $-11,52893$ & 0,0000 \\
\hline $\begin{array}{c}\text { Sigma square } \\
=0.199185\end{array}$ & $\begin{array}{c}\text { Log likelihood } \\
=-143.3357\end{array}$ & AIC & Adj. R-squar & SIC \\
\hline
\end{tabular}

Source: the authors.

regarding the volatility pattern of the CPI in Croatia at the same time. If we hold the significance level at $1 \%$ the variance of the model presented in Table 3 will be heteroscedastic indicating volatility clustering. So we test several ARCH family models to remove heteroskedasticity out of the residuals and obtain the information on CPI volatility in Croatia. The ARCH family models we test are specified in equations (11) up to (15) and the results are summarized in Table 4.

Following the information criteria and significance of the variables reported in Table 4, ARCH (1) model is the most appropriate one to describe the CPI volatility development in Croatia. The estimated model is stable since all roots have modulus less than one and lie inside the unit circle, and correlogram indicates no autocorrelation in residuals up to leg thirty-six. Following Jarque-Bera tests, residuals in the estimated model are normally distributed. Following the results in Table 4, the estimated model can be accepted.

\section{Concluding remarks}

The existing literature points to ARIMA model as an efficient and accurate one to forecast inflation in different countries and regions. Results of this research support the findings of the existing literature. We found no empirical evidence that negative and positive shocks imply different future volatility of monthly CPI. Out of compared Akaike information criterion (AIC), Schwarz Criterion (SC) and significance for each component in all of the specified volatility models the conclusion is that ARCH (1) is the best fitted model to describe inflation volatility in Croatia.

Due to high euroization in Croatian banks and therefore financial stability, monetary policy in Croatia directed toward exchange rate and inflation remains as a foreign-driven phenomenon. In given economic circumstances, ARIMA $(0,1,1) \times(0,1,1)_{12}$ model is fitted as the one describing CPI pattern behavior and therefore reliable for $\mathrm{CPI}$ forecasting. Furthermore, $\mathrm{CPI}$ volatility in Croatia seems to be a common feature and ARCH (1) model is found to be the best fitted one in explaining its development.

Table 4 Volatility estimates for CPI in Croatia

\begin{tabular}{|c|c|c|c|c|c|}
\hline Parameter & $\operatorname{ARCH}(1)$ & $\operatorname{GARCH}(1,1)$ & TARCH & EGARCH & PARCH \\
\hline \multirow{2}{*}{$\omega$} & 0.120444 & 0.082680 & 0.084167 & -1.335287 & 0.285743 \\
\hline & $(0.0000)$ & $(0.0092)$ & $(0.0086)$ & $(0.0033)$ & $(0.1172)$ \\
\hline \multirow{2}{*}{$\alpha$} & 0.420315 & 0.395617 & 0.457660 & 0.599610 & 0.152959 \\
\hline & $(0.0000)$ & $(0.0009)$ & $(0.0058)$ & $(0.0010)$ & (0.1011) \\
\hline \multirow{2}{*}{$\beta$} & & 0.211996 & 0.194695 & 0.505738 & 0.547007 \\
\hline & & $(0.2574)$ & $(0.2847)$ & $(0.0229)$ & $(0.0000)$ \\
\hline \multirow{2}{*}{$\gamma$} & & & & 0.057174 & \\
\hline & & & $(0.6664)$ & $(0.5644)$ & $(0.3651)$ \\
\hline \multirow{2}{*}{$\delta$} & & & & & 0.088355 \\
\hline & & & & & $(0.8818)$ \\
\hline ARCH - LM Test & $(0.4453)$ & $(0.5995)$ & $(0.5898)$ & $(0.6984)$ & $(0.8830)$ \\
\hline $\mathrm{AIC}$ & 1.142189 & 3.502555 & 1.153244 & 1.142798 & 1.116901 \\
\hline SC & 1.202730 & 3.532920 & 1.244054 & 1.233609 & 1.222847 \\
\hline Obs & 227 & 227 & 227 & 227 & 227 \\
\hline
\end{tabular}

Source: the authors. 


\section{Literature}

Bokhari, S. M., Feridun, M. (2006) Forecasting Inflation through Econometric Models: An Empirical Study on Pakistani Data. Doğuş Üniversitesi Dergisi, 7 (1): 39-47.

Bollerslev, T. (1986) Generalized Autoregressive Conditional Heteroscedasticity. Journal of Econometrics, 31 (6): 307-327.

Botrić, V., Cota, B. (2006) Sources of Inflation in Transition Economy: The Case of Croatia. Ekonomski pregled, 57 (12): 835-855.

Box, G. E.P.,Jenkins, G. M. (1976) Time Series Analysis, Forecasting and Control, Holden-Day. San Francisco.

Chmelarova,V., Schnabl,G.(2006) Exchange Rate Stabilization in Developed and Underdeveloped Capital Markets. Available at: https://www.ecb.europa.eu/pub/pdf/scpwps/ecbwp636.pdf [15.8.2016].

Cryer,J. D., Chan, K. S. (2008) Time series analysis with application in R. New York: Springer.

Ding, Z., Granger, C. W. J., Engle, R. F. (1993) A Long Memory Property Of Stock Market Returns And A New Model. Journal of Empirical Finance, 1 (1): 83-106.

Engle, R.F.(1982) Autoregressive Conditional Heteroscedasticity with Estimates of the Variance of United Kingdom Inflation. Econometrica, 50 (4): 987-1007.

Erjavec, N., Cota, B. (2007) Modeling stock market volatility in Croatia. Economic Research, 20 (1): 1-7.

Espasa, A., Poncela, P., Senra, E. (2002) Forecasting monthly US consumer price indexes through a disaggregated I(2) Analysis. Statistics and Economic Series 1, Universidad Carlos III de Madrid working paper 02-03.

Etuk, E. H., Uchendu, B., Victoredema, U. A. (2012) Forecasting Nigerian Inflation Rates by a Seasonal ARIMA Model. Canadian Journal of Pure and Applied Sciences, 6 (3): 2179-2185.

Fritzer, F., Moser, G., Scharler, J. (2002) Forecasting Austrian HICP and its Components using VAR and ARIMA Models. OeNB Working Paper, No.73, Vienna.

Globan, T., Arčabić, V., Sorić, P. (2016) Inflation in New EU Member States: A Domestically or Externally Driven Phenomenon. Emerging markets finance and trade, 52 (1): 154-168.

Glosten, L. R., Jagannathan, R., Runkle, D. E. (1993) On the Relation between the Expected Value and the Volatility of the Nominal Excess Return on Stocks. Journal of Finance, 48 (5): 1779-1801.

Goodfriend, M. (2007) How the World Achieved Consensus on Monetary Policy. The Journal of Economic Perspectives, 21 (4): 47-68.

Hill, G., Fildes, R. (1984) The accuracy of extrapolation methods: An Automatic BoxJenkins package (SIFT). Journal of Forecasting, 3: 319-323.

Hubrich, K. (2005) Forecasting Euro Area Inflation: Does Aggregating Forecasts By HICP Component Improve Forecast Accuracy? International journal of Forecasting, 21 (1): 119-136.

Joyce, M., Miles, D. Scott, A., Vayanos, D. (2012) Quantitative Easing and Unconventional Monetary Policy - an Introduction. The Economic Journal, Royal Economic Society. Available at https://workspace.imperial. ac.uk/business-school/Public/people/dmiles/Analytical_6616470_1.PDF [25.8.2016].

Kelikume, I., Salami, A. (2014) Time Series Modeling And Forecasting Inflation: Evidence From Nigeria. The International Journal of Business and Finance Research, 8 (2): 41-51.

Libert, G. (1983) The M-competition with a Fully Automatic Box-Jenkins Procedure. International Journal of Forecasting, 2: 325-328.

Madsen, H. (2008) Time Series Analysis. Chapman \& Hall/CRC, London Priestley, MB.1981. Spectral Analysis and Time Series. London: Academic Press. 
Živko, I., Bošnjak, M.

Time Series Modeling of Inflation and its Volatility in Croatia
Mance, D., Žiković, S., Mance, D. (2015) Econometric Analysis of Croatia’s Proclaimed Foreign Exchange Rate. South East European Journal of Economics and Business, 10 (1): 7-17.

Nelson, D. B. (1991) Conditional Heteroscedasticity in Asset Returns: A New Approach. Econometrica, 59 (2): $347-370$

Palić, I., Dumičić, K., Šprajček, P. (2014) Measuring real exchange rate misalignment in Croatia: cointegration approach. Croatian Operational Research Review, 5 (2): 135-148.

Payne, J. E. (2002) Inflationary Dynamics of a Transition Economy: the Croatian Experience. Journal of Policy Modeling, 24 (3): 219-30.

Poulos, L., Kvanli,A., Pavur, R. (1987) A comparison of the accuracy of the Box-Jenkins method with that of automated forecasting model. International Journal of Forecasting, 3: 261-267.

Priestley, M. B. (1981) Spectral Analysis and Time Series. London: Academic Press.

Pufnik,A., Kunovac, D. (2006) Kratkoročno prognoziranje inflacije u Hrvatskoj korištenjem sezonskih ARIMA procesa, Istraživanja, I-18,Zagreb, Croatian National Bank.

Texter, P.A., Ord, J. K. (1989) Forecasting Using Automatic Identification Procedures: A comparative Analysis. International Journal of Forecasting, 5: 209-215.

Vizek, M.,Broz, T. (2009) Modeling inflation in Croatia. Emerging Markets Finance and Trade, 45 (1): 87-98.

Zakoian, J. M. (1994) Threshold Heteroskedastic Models. Journal of Economic Dynamics and Control, 18 (5): $931-952$ 
Figure 2 Autocorrelation and Partial Correlation of monthly CPI in Croatia

Included observations: 227

\begin{tabular}{|c|c|c|c|c|c|c|c|}
\hline \multicolumn{2}{|c|}{ Autocorrelation } & \multicolumn{2}{|l|}{ Partial Correlation } & \multirow{2}{*}{$\frac{A C}{0.944}$} & \multirow{2}{*}{$\begin{array}{l}\text { PAC } \\
0.944\end{array}$} & \multirow{2}{*}{$\begin{array}{l}\text { Q-Stat } \\
205.02\end{array}$} & \multirow{2}{*}{$\begin{array}{l}\text { Prob } \\
0.000\end{array}$} \\
\hline 1 & & $1 F$ & 1 & & & & \\
\hline 1 & & 1 & 2 & 0.877 & -0.129 & 382.83 & 0.000 \\
\hline 1 & & וp & 3 & 0.819 & 0.057 & 538.61 & 0.000 \\
\hline 1 & & 111 & 4 & 0.768 & 0.009 & 675.93 & 0.000 \\
\hline 1 & & 1 & 5 & 0.710 & -0.086 & 793.99 & 0.000 \\
\hline 1 & & 11 & 6 & 0.652 & -0.024 & 893.86 & 0.000 \\
\hline 1 & & 11 & 7 & 0.595 & -0.019 & 977.63 & 0.000 \\
\hline 1 & $\square$ & cํ 1 & 8 & 0.533 & -0.103 & 1045.1 & 0.000 \\
\hline 1 & $\square$ & 11 1 & 9 & 0.469 & -0.037 & 1097.6 & 0.000 \\
\hline 1 & $\square$ & ㄴ. & 10 & 0.393 & -0.163 & 1134.6 & 0.000 \\
\hline 1 & $\square$ & 다 1 & 11 & 0.307 & -0.149 & 1157.3 & 0.000 \\
\hline 1 & $\square$ & וp & 12 & 0.232 & 0.054 & 1170.3 & 0.000 \\
\hline 1 & $\emptyset$ & $1 \square$ & 13 & 0.198 & 0.301 & 1179.8 & 0.000 \\
\hline 1 & $\square$ & 101 & 14 & 0.172 & -0.001 & 1187.1 & 0.000 \\
\hline 1 & $\square$ & 10 & 15 & 0.137 & -0.064 & 1191.7 & 0.000 \\
\hline 1 & 吕 & 11 & 16 & 0.102 & 0.012 & 1194.2 & 0.000 \\
\hline 1 & । & 141 & 17 & 0.071 & -0.051 & 1195.5 & 0.000 \\
\hline 1 & b. & $1]_{1}$ & 18 & 0.046 & 0.044 & 1196.0 & 0.000 \\
\hline 1 & 1 & 101 & 19 & 0.022 & -0.001 & 1196.1 & 0.000 \\
\hline 10 & 1 & 111 & 20 & 0.002 & -0.024 & 1196.1 & 0.000 \\
\hline 1 & 1 & Id 1 & 21 & -0.012 & 0.006 & 1196.2 & 0.000 \\
\hline 1 & 1 & IL 1 & 22 & -0.021 & -0.079 & 1196.3 & 0.000 \\
\hline 1 & 1 & Id 1 & 23 & -0.021 & -0.006 & 1196.4 & 0.000 \\
\hline 14 & 1 & 111 & 24 & -0.026 & -0.013 & 1196.5 & 0.000 \\
\hline 10 & 1 & । & 25 & -0.026 & 0.191 & 1196.7 & 0.000 \\
\hline 11 & 1 & $\sqrt{1}$ & 26 & -0.034 & -0.111 & 1197.0 & 0.000 \\
\hline 10 & 1 & 10 & 27 & -0.037 & -0.006 & 1197.4 & 0.000 \\
\hline 1 & 1 & 1 & 28 & -0.035 & 0.014 & 1197.7 & 0.000 \\
\hline 1 & 1 & וך ו & 29 & -0.024 & 0.077 & 1197.8 & 0.000 \\
\hline 11 & 1 & I & 30 & -0.022 & -0.082 & 1198.0 & 0.000 \\
\hline 10 & 1 & 回 1 & 31 & -0.029 & -0.084 & 1198.2 & 0.000 \\
\hline 11 & 1 & 17 & 32 & -0.032 & 0.029 & 1198.5 & 0.000 \\
\hline 10 & 1 & 1 & 33 & -0.030 & 0.039 & 1198.7 & 0.000 \\
\hline 10 & 1 & IL 1 & 34 & -0.031 & -0.072 & 1199.0 & 0.000 \\
\hline 11 & 1 & וך 1 & 35 & -0.029 & 0.083 & 1199.2 & 0.000 \\
\hline 10 & 1 & Id 1 & 36 & -0.026 & -0.026 & 1199.4 & 0.000 \\
\hline
\end{tabular}

Živko, I., Bošnjak, M.

Time Series Modeling of Inflation and its Volatility in Croatia

Source: the authors. 
